\title{
О ИМЕНИЦАМА СА СЕКУНДАРНИМ ЗНАЧЕЊЕМ НОСИОЦА КАРАКТЕРНЕ ОСОБИНЕ У РЕЧНИКУ СРПСКИХ ГОВОРА ВОЈВОДИНЕ
}

\begin{abstract}
У раду су анализиране лексеме којима се именују особе са одређеном карактерном особином у српским војвођанским говорима, и то именице коју су у процесу семантичке деривације стекле такво номинационо својство. Грађа за истраживање је ексцерпирана из Речника српских говора Војводине, најобимнијег дијалекатског речника у којем је представљена лексика ових говора. С обзиром на тип грађе, значења лексема су посматрана као скуп семантичких компонената. Издвојене су најважније групе именица за које је карактеристична та врста трансформације примарног семантичког садржаја. Такође, описане су одређене специфичности метафоричког и метонимијског преноса номинације на примеру анализираних лексема, а указано је и на ареалну распрострањеност и статус појединих семантичких реализација.
\end{abstract}

Кључне речи: српски језик, војвођански говори, именице, карактерне особине, семантичка деривација, метафора, метонимија.

\section{1. Увод}

Највећи део семантичких реализација које се у одређеном језичком идиому односе на човека именованог према некој карактерној³ особини

\footnotetext{
${ }^{1}$ nikola.sankovic@isj.sanu.ac.rs

${ }^{2}$ Овај рад је настао у оквиру пројекта 178009 Лингвистичка истраживања савременог српског књижевног језика и израда Речника српскохрватског књижевног и народног језика САНУ, који у целини финансира Министарство за просвету и науку Републике Србије. Рад представља измењену верзију једног дела семинарског рада из курса Лексика српског језика на докторским студијама на Филолошком факултету у Београду, који је рађен под менторством проф. др Рајне Драгићевић.

${ }^{3}$ Појмове карактер и карактерни овде узимамо нешто шире, тако да обухватају и моралне и интелектуалне особине човека, а у складу са дефиницијом основног значења лексеме карактер у Речнику САНУ - „скуп битних, изразитих и сталних морално-психичких и интелектуалних особина појединца или заједнице, које се испољавају у погледима и поступцима, у односу према средини, морално-психички лик; природа, ћуд” (уп. ШТАСНИ 2013: 92; МИЛОСАВЉЕВИЋ 2014: 232). У недостатку јаснијег и прецизнијег краћег термина који би обухватао људске особине које се не сврставају у физичке, у овом раду ће бити коришћен термин карактерне особине.
} 
настаје било стварањем нове лексеме у творбеном процесу (тј. творбеном деривацијом) било искоришћавањем јединица које већ постоје у лексичком систему за ново, секундарно именовање (тј. семантичком деривацијом). Секундарна номинација заснована је, као и код већине других именичких семантичких скупина, првенствено на метафори и метонимији као лексичким механизмима. Мотиватори полисемичких ширења тог типа најчешће су конотативне семантичке компоненте, а резултат су нова значења постојећих лексема, која се у овом случају односе на носиоце карактерних особина. Када су метафоричке асоцијације подстакнуте конотативним семама, у прототипичним случајевима полазне лексеме припадају класи именица којима се примарно денотирају животиње (и биљке) или човек, а добијене семантичке реализације су експресивно маркиране, и то најчешће негативно (в. ГОРТАН-ПРЕМК 2004: 107). Један број лексема за именовање човека по одређеној особини преузет је директно из страних језика са одговарајућим значењем, док су неке од позајмљеница, после адаптације, ушле у уобичајене творбено-семантичке процесе као мотивне речи у творби нових јединица или као полазне лексеме у секундарној номинацији. ${ }^{4}$

Предмет овог истраживања су именичке лексеме које су у процесу семантичке деривације постале средство за именовање носилаца карактерних особина у српским говорима Војводине. Грађа за истраживање преузета је из Речника српских говора Војводине (РСГВ), у који је ушла углавном лексика са простора шумадијско-војвођанског дијалекта, односно његовог војвођанског поддијалекта, а мањим делом из смедеревско-вршачког дијалекта и других, мањих говорних зона.

Када се узму у обзир све именице у РСГВ са бар једном семантичком реализацијом која се односи на човека као носиоца одређене карактерне особине, може се закључити следеће: а) већина тих именица су моносемичне лексеме; б) најбројније су суфиксалне творенице; в) нешто више од трећине корпуса чине полисемичне речи, и то именице са по два издвојена значења (на носиоце карактерних особина односе се, очекивано, углавном секундарне реализације полисемичних лексема). Дакле, именице анализиране у овом истраживању представљају мањи део (око једне трећине) свих именица којима се именују носиоци карактерних људских особина у РСГВ. ${ }^{6}$

\footnotetext{
${ }^{4}$ Основне појмовно-терминолошке поставке у овом истраживању засноване су углавном на двама општим приручницима србистичке лексикологије - Полисемија и организација лексичког система у српскоме језику (ГОРТАН-ПРЕМК 2004) и Лексикологија српског језика (ДРАГИЋЕВИЋ 2007).

${ }^{5}$ Овај речник спада у ред најзначајнијих дела савремене српске дијалектолошке лексикографије. Речничка грађа захвата шири дијалекатски простор војвођанског поддијалекта, који укључује различите мање дијалекатске говоре, односно говорне заједнице, са специфичностима како језичке тако и ванјезичке - социјалне и културолошке природе.

${ }^{6}$ Овом тематиком бавиле су се у два коауторска рада Д. Станић и Ј. Јанковић - „Пејоративни називи за мушка лица у српским народним говорима на територији Војводине” и „Пејоративни називи за женска лица у српским говорима Војводине”. Пејоративима су у
} 
Значење анализираних лексичких јединица посматрано је у овом истраживању као скуп семантичких компонената. Прототипична значења лексема којима се именују носиоци карактерних особина могу се, према тој концепцији, разложити на архисему - 'људско биће', 'особа' и на диференцијалне компоненте, у дефиницијама најчешће представљене одговарајућим придевом са значењем особине (односно већим бројем оваквих придева). ${ }^{7}$ На основу тога су издвојене и анализиране најбројније групе именица са секундарним значењем носиоца одређене карактерне особине.

Циљ истраживања је да се опишу специфичности семантичке деривације са значењем носиоца карактерне особине као циљним садржајем у датом дијалекатском говору: најважније лексичке групе за које је карактеристична таква трансформација примарне семантике, неке посебности метафоризације зоонима и друге лексике, метонимијске трансформације апстрактних именица, ареална распрострањеност и статус одређених семантичких реализација.

\section{2. Значења добијена метафоричким трансформацијама}

2.1. Секундарна значења именица које денотирају човека са одређеном карактерном особином најчешће су резултат метафоричког преноса номинације, док су остали механизми полисемије, метонимија и синегдоха, знатно мање продуктивни, као што ће у раду бити показано. Најпродуктивније извориште оних метафоричких трансформација које имају као циљни садржај значење носилаца карактерних особина у РСГВ јесте зоонимска лексика. Зоонимима се именује и највећи број носилаца различитих људских особина, међу којима је доминантна особина умне, интелектуалне ограничености, односно глупости. У РСГВ носиоце те особине именују у својим секундарним реализацијама лексеме во, волина, говедо, говече, гуска, коза $(3)^{8}$, кокошка, кою, коњина, магарач (2a), магарица, мазгов (2a), мула, овиза,

овим истраживањима сматрани готово сви непожељни називи за мушку, односно женску особу.

\footnotetext{
${ }^{7}$ Именице којима се означавају носиоци карактерних особина припадају типу лексике чијем семантичком садржају не одговара у потпуности компоненцијална анализа. Важан део њиховог значења чине апстрактне особине, изражене придевима људских особина, за које понекад није погодна та врста семантичке анализе. Међутим, с обзиром на то да је за истраживање коришћена искључиво речничка грађа, значења лексема представљена су речничким дефиницијама, на основу којих се именичке лексеме могу, мање или више поуздано, разложити на основне семантичке компоненте. Понекад се једини подаци о значењу одређене речи могу добити из дефиниције, јер недостају одговарајући примери којима се илуструје употреба лексеме у датом значењу.

${ }^{8}$ Број значења у полисемичкој структури у РСГВ наводимо само код оних лексема које имају више различитих значења која се односе на носиоце карактерних особина.
} 
сивоња, теле, ћурак и ћурка. Од осталих карактерних особина у секундарним значењима чланова ове лексичке групе нешто заступљеније су особине: а) злобе: бештија9 'зла жена' - „Жена му је права бештија”, зоља (2a) 'зла, пакосна жена', куја 'зла, рђава женска особа', кучка 'зла, рђава женска особа; неморална женска особа', скот 'зла, немилосрдна, подла особа' - „Баш је скот кад рођену сестру туче", шкорпија 'зла жена'; б) тврдоглавости: бедевија 'висока крупна жена; тврдоглава жена', магарац (2б) 'тврдоглав човек', магаре 'безобразно дете; тврдоглаво дете', магариияа 'глупача; тврдоглава жена', мазгов (2б) 'тврдоглав човек'; и в) несташности: зоља (2б) 'несташна девојчица', јаре 'немирно, несташно дете', коза (2) 'веома несташна девојчица', пундрав ${ }^{10}$ 'немирна, несташна особа (обично дете); особа која не може дуго да се задржи на једном месту', штене 'дете, дечак (обично несташан, непослушан)' - „Кад пође у школу, валда ће се уозбиљити, а сад је право штене".

Новија истраживања зоонимских метафора у савременом српском језику, рађена првенствено на грађи из описних речника српског језика (РАНЪЕЛОВИЋ 2012; НОВОКМЕТ 2016; ЈОВАНОВИЋ 2018), потврђују постојање одређених општих карактеристика зоонима у сфери карактерних људских особина: а) метафоричке трансформације засноване су пре свега на конотативним семама, а њихов резултат су готово увек семантичке реализације негативне експресивности (мањег или већег интензитета); б) циљни садржај метафоризације односи се у највећем броју случајева на носиоце особина које се тичу људске интелигенције - умна ограниченост, глупост, и морала - злоба, рђавост и сл. ${ }^{11} \mathrm{C}$ обзиром на то да је у наведе-

\footnotetext{
${ }_{9}^{9}$ У групу зоонима уврштене су и поједине именице које у основном значењу представљају хиперониме зоонимских лексема: бештија 'животиња; звер', марва 'зб домаће животиње (обично крупнија рогата стока, говеда)' и скот 'четвороножна животиња'.

${ }^{10}$ Основно значење ове лексеме према РСГВ јесте 'глиста која као паразит живи у дебелом цреву човека и коња Oxуurus vermicularis'. Нису одмах уочљиве семантичке компоненте које су могле мотивисати асоцијативно повезивање са несташним дететом / немирном особом. Та веза нешто је јаснија када се погледају примери наведени као илустрација примарног значења ове именице у РСГВ: - „Шта си се узврпољијо ко да имаш пундрава”; 'прен' - „Ти, изгледа, имаш пундрава у туру?”. Значење носиоца карактерне особине могло је настати трансформацијом овог типа: животиња која има пундрава је немирна $\rightarrow$ немирна особа понаша се као животиња која има пундрава $\rightarrow$ немирна особа је пундрав. У питању је здружено деловање метафоре и метонимије (односно метафтонимија). Друга могућност за извођење значења носиоца карактерне особине јесте његово директно метафоричко повезивање са примарним значењем именице пундрав: пундрав је животиња која је 'немирна', тј. која се стално помера, креће $\rightarrow$ немирно дете / немиран човек је пундрав. У семантичкој структури ове именице, како је она представљена у РСГВ, не постоје компоненте које се односе на начин кретања које би могле мотивисати метафоричке асоцијације.
}

${ }^{11}$ Према истраживању А. Ранђеловић (2012), рађеном на грађи из једнотомног Речника српскога језика (РСJ), метафорична значења зоонима најчешће се односе на носиоце особина злобе и глупости, с тим што је у РСЈ нешто већи број зоонима са секундарним значењем зле 
ним истраживањима са различитих аспеката разматрана готово целокупна зоонимска лексика коју региструје РСГВ, као и да се семантичке карактеристике те лексике из овог речника и из дескриптивних речника књижевног језика преклапају у великој мери, што показује и пример најзаступљенијих карактерних особина (глупости и злобе), овде ћемо указати само на извесне разлике у односу на грађу из тих речника.

Неколико зоонима у РСГВ реализује секундарна значења носилаца карактерних особина која нису регистрована у описним речницима књижевног језика: бумбар/бумбор 'трома, лења особа'; вижле 'спретна, лукава особа' ('ловачки пас') 12; еја 'мудра, довитљива особа' - „Еја једна, све она зна унапред' ('ноћна птица грабљивица, сова'); јаре 'немирно, несташно дете'; кер и кера 'прека, љутита, бесна особа'; пастув 'похотљив човек'; пуле 'дете које је превише привржено мајци' - „Пуле једно, само се држи мами за сукњу” ('магаре', односно 'ждребе'); пулин 'сервилна особа, полтрон' „Он је Живин пулин” ('мали овчарски пас'); шкорпија 'зла жена'. ${ }^{13}$ Мотивисаност секундарне номинације у наведеним примерима углавном је транспарентна, заснована је на конотативним семама, које имају исходиште у одређеним карактеристикама наведених животиња, односно животињских врста. У случају лексеме бумбар/бумбор полазно је могло бити и зоонимско значење 'трут' и пренесено значење које се односи на физичку особину 'крупно, пуначко дете или, ређе, одрасла особа'. Није потпуно јасна веза између наведених значења лексеме еја, јединог зоонима којим се у РСГВ именује особа са изразито позитивном особином. Синоним ове лексеме - сова

особе. У најобимнијој студији о зоонимској метафори у српском језику С. Новокмет (2016) такође је утврдио да су ове негативне особине најзаступљеније. Према том истраживању, секундарна значења носилаца карактерних особина „којима је заједничка компонента злобе” реализује преко тридесет зоонима, а приближан је број и зоонимских лексема са значењем особа које се одликују блиским особинама рђавости, покварењаштва и сл. (НОВОКМЕТ 2016: 409-410). Значења особе са смањеним интелектуалним капацитетима реализује више десетина лексема - „на глупост упућује 56 примера [...] док на особину БудАлА [...] у комбинацији са особином глупости, упућује укупно 15 примера" (НОВОКМЕТ 2016: 380). Као најважније карактерне, односно 'духовне' особине које се приписују човеку преко зоонимских лексема Ј. Јовановић (2018: 176) издваја особину глупости и „општу негативну карактерну црту која припада сфери моРАлности и могла би се подвести под злоьу/РЂАвост/ БЕзОБзиРНОСт/НЕмОРАЛност". У примарне изворе грађе, поред основних дескриптивних речника, укључена су и два речника жаргона, тако да је број зоонима који денотирају глупу особу (37 лексема) нешто већи у односу на зоонимске лексеме са значењем зле, подмукле, неморалне особе (29 лексема) (ЈОВАНОВИЋ 2018: 176, 178).

${ }^{12}$ У загради иза значења добијеног у процесу полисемичког ширења (и илустрације тог значења) наводи се примарно значење одговарајуће лексеме, односно полазно значење у метафоричком преносу номинације, уколико та лексема није општепозната.

${ }^{13}$ Неке од побројаних именица (бумбар, вижле, кер, кера) регистроване су у речницима књижевног језика са секундарним значењем носилаца неких других особина (углавном карактерних, ређе физичких). Лексему шкорпија у значењу које је блиско наведеном даје и Велики речних страних речи и израза (уп. НОВОКМЕТ 2016: 306, 406). 
не доводи се у описним речницима књижевног језика, као ни у самом РСГВ, у везу са особином мудрости. ${ }^{14}$ Међутим, извесно је да постоји таква веза у менталном лексикону говорника српског језика. То јасно показују реакције на стимулусе мудар и мудра у АРС , где је лексема сова седма реакција по фреквенцији и на основни облик придева мудар и на облик женског рода у једнини тог придева - мудра. ${ }^{15}$

Специфичност у РСГВ представља и приказана лексичка скупина зоонима са придевском компонентом 'несташан' ${ }^{16}$ у семантичком садржају, која се не издваја као посебно важна у поменутим истраживањима. Такође, иако не припада прототипичној зоонимској лексици, овде истичемо групу лексема којима се именује тело угинуле (обично крупније) животиње. Те лексеме развијају секундарна значења особа које су склоне нераду, беспослености и сл.: мрцина 'рђава, лоша, безвредна особа; ленштина' - „Мрцино једна, само лежиш на том отоману"; стрвина 'веома лењ човек, нерадник' - „Иди пробуди ону стрвину да му ја не уђем и да га шиљем на радњу”; цркотина 'особа која ништа не ради, ленштина'. Метафоризација је у овом случају, чини се, заснована на имплицитним компонентама значењског садржаја које се односе на непокретност тела угинуле животиње, ${ }^{17}$ a део мотивације за овај пренос свакако је и у вези са повећањем степена експресивности, што се постиже спуштањем људског бића на још нижи појмовни ниво од животињског. ${ }^{18}$ Уколико наведене лексеме придружимо зоонимима,

\footnotetext{
${ }^{14}$ Како показује С. Новокмет, углавном на примерима из речника жаргона, овим зоонимом се именује глупа особа, женска особа привлачног изгледа, проститутка итд. (НОВОКМЕТ 2016: $315,378,473)$. Ни код других синонима лексеме еја - буљина, јејина у речницима није регистрована конотативна компонента значења која се односи на особину мудрости.

${ }^{15}$ Највероватније је ова конотативна компонента новијег порекла и резултат прихватања садржаја из других култура, с обзиром на то да се у словенској традицији сова не доводи у везу са особином мудрости.

${ }^{16}$ Особина означена придевом 'несташан', као и блискозначним придевом 'немиран', најистакнутија је карактерна особина чији је носилац дете и, према речничким дефиницијама, налази се у семантичком садржају још десетак именица у РСГВ.

${ }^{17}$ На асоцијативну везу између 'некретања' и особине лењивости указује и пример из призренског говора, где се лексема крл'а, у значењу 'пањ', реализује као негативна квалификација човековог односа према раду (в. МИЛОСАВљЕВИЋ 2014: 234).
}

${ }^{18}$ Исто примарно значење као наведене именице има и лексема ирканица, у чијој полисемичкој
структури, према РСГВ, нема очекиване семантичке реализације која се односи на лењу
особу. Међутим, израз који је наведен уз ову именицу - вући се као ирканица 'понашати
се безвољно, лењо', указује на исту асоцијативну везу која је довела до развоја таквих
секундарних значења. Семантички блиска наведеним лексемама је и именица мрледина, која
у РСГВ има значење 'лења особа, ленштина'. Ова именица се уклапа у варијантни низ лексема
мрледина, мрлина, мрлина, са значењем 'леш', које се могу пронаћи у другим речницима
српског језика. У речнику П. Скока ове именице се изводе од глаголског корена мрл- (који је
служио за творбу речи од глагола мрети). Дакле, и овде је у питању исти тип метафоричког
повезивања, с тим што примарно значење именице мрљедина, односно полазно значење у 
поред већ приказаних мањих тематских скупина можемо издвојити и ону која обухвата зоониме са секундарним значењем лење, нерадне особе. Тој групи поред наведених лексема припадају и лексеме бумбар/бумбор, квочка, марва, трунташ и трут.

Лексема самсов забележена је само на једном пункту у значењу 'глуп, блесав човек'. У РС ова лексема има примарно значење 'крупан, велики пас'. Према речнику П. Скока, у питању је турцизам грчког порекла, са прилагођавањем финалне фонеме именицама са формантом -ов. Може се претпоставити да је значење регистровано у РСГВ настало метафоричким преношењем номинације ${ }^{19}$, с тим што је примарни, зоонимски садржај изгубљен у датом дијалекатском говору или није ушао у речничку грађу. ${ }^{20}$

На значај ове лексичко-семантичке групе указују и одређени подаци о ареалној распрострањености, који се могу добити из речничког чланка у РСГВ. Наиме, иза потврда за неко значење у овом речнику наведене су скраћенице за пунктове на којима је то значење забележено. ${ }^{21}$ То можемо сматрати индиректним обавештењем о статусу одређених лексема, односно појединих лексичких значења, у оквиру целог поддијалекта. И према том критеријуму зооними су најзначајнија лексичка група у сфери карактерних људских особина. Они чине готово половину лексема које су у одговарајућим семантичким реализацијама потврђене на пет и више различитих пунктова. Значајну распрострањеност, према наведеном критеријуму, у значењима која се односе на човека са одређеном карактерном особином, имају зоонимске лексеме ћурка (18 пунктова), кобила 'жена, обично крупна, груба; неморална жена' (16); шуша 'неспособна, безвредна особа; особа без имало угледа, ништарија' ('крава, коза или овца без рогова') (15), скот (13), гуска (12), коњ (11), бештија (10), цукела (9), коза (8), магарац (7), кукавица, мазгов и штене (6), ајгир, во, лисица, трут и ћурак (5 пунктова). ${ }^{22}$

метафоричкој трансформацији, није забележено у РСГВ.

${ }^{19} \mathrm{У}$ различитим истраживањима уочена је асоцијативна веза између семантичког поља интелигенције и одређених физичких особина (нпр. крупне грађе) (уп. нпр. НОВОКМЕТ 2016: 380; ЈОВАНОВИЋ 2018: 183).

${ }^{20}$ У српском призренском говору, где ова лексема има форму ближу изворној самсон, регистрована су оба значења - 'велики пас', односно 'неотесан, груб човек' (МИЛОСАВљЕВИЋ 2014: 233).

${ }^{21}$ У РСГВ је ушла лексика из великог броја извора, који у различитој мери обухватају дијалекатски простор (од једног насеља до целе територије Војводине), те свака лексема (или семантичка реализација) није испитивана на свим забележеним пунктовима. Стога, податак који овде дајемо о броју пунктова, односно ареалној заступљености треба ипак узимати условно.

${ }^{22}$ На основу података о броју потврда неког значења може се претпоставити да су у одређеним случајевима пренесена незоонимска значења постала доминантна (нпр. лексема скот незоонимско значење је потврђено на 13 пунктова, а зоонимско на 3 пункта). 
2.2. Друга важна група лексема у којој се јавља овај тип метафоричких преноса обухвата именице које денотирају човека и у основном значењу. Семантички најпродуктивнија је подгрупа именица са значењем особе која се бави неким послом, која има одређено занимање, службу или друштвени статус, положај, која врши одређене радње, активности и сл. Лексичка метафора у том случају може бити заснована на различитим семантичким компонентама примарног садржаја: а) на конотативним семама: беамтер 'беспосличар' ('чиновник, службеник') 23; немеш (2a) 'надмен, охол човек који се понаша заповеднички; умишљени земљорадник, сељак који се понаша господски', (2б) 'лењ човек, онај који живи на туђ рачун' ('ситни угарски племић'); салашанка 'проста, примитивна женска особа'; тутор 'који све зна најбоље, који свима дели савете'24; фишкал 'мудријаш, довитљивац; лукавац, препредењак' ('правни заступник, бранилац; саветодавац у правним питањима'); цамбас (2a) 'прека, опака особа', (2б) 'препредењак, превејанац, варалица' ('познавалац коња; трговац коњима; препродавац коња'); б) на различитим диференцијалним семама које се односе на реална обележја особе: акробата 'вешт, сналажљив, спретан човек'; комедијаш 'шаљивџија'; целат 'непријатељ, злотвор, крвник; бездушна, немилосрдна особа'.

Полазни садржај приликом секундарног именовања особа које поседују неку карактерну особину понекад је и значење човека као носиоца одређене физичке особине. Тај тип метафоризације налазимо код неколико именица у РСГВ: богаљ 'неспособна, неспретна особа којој ништа не полази за руком'; гадов 'некарактерна, покварена личност' ('ружан човек'); гузоња 'дебео човек, често нерадник, готован'; жвалоњ $а$ 'онај који је недорастао, незрео'; килоња 'неспособна, слаба, неспретна, спора особа'; мељов 'гојазан, дебео човек; тром, лењ човек'.

На највећем броју пунктова потврђена су наведена метафоричка значења лексема килоњ а (10 пунктова), богаљ (8), гадов (5) - дакле, именица којима се примарно именује човек према физичкој особини.

Од осталих лексичких група са човеком као изворним садржајем у процесу другостепене номинације, издвајамо и групу лексема са значењем одређених родбинских релација, чија одговарајућа секундарна експресивна значења такође настају активирањем сема колективне експресије: баба 'плашљив човек, кукавица'; свекрва/свекрова 'која се понаша као свекрва, која стално критикује и наређује' и стрина 'плашљив човек, кукавица, страшљивац’.

\footnotetext{
${ }^{23}$ Није потпуно сигурно да постоји асоцијативна веза између примарног и секундарног значења. Могућој повезаности ових значења у прилог иде и значење лексеме беамтер у РСАНУ: 'службеник у канцеларији (често с потцењивањем)'.

${ }^{24}$ Основно и прво секундарно значење у РСГВ су: 1. 'лице које се брине и стара о малолетним и хендикепираним особама'. 2. 'световна особа која се брине за цркву и црквене ствари'.
} 
Номинација мотивисана стереотипом према одређеној етничкој заједници веома је слабо заступљена у грађи из РСГВ. Притом, основна значења етнонима углавном нису навођена: циган и цүиганин 'непоштен, рђав човек', чивут 'штедљива особа, тврдица' ${ }^{25}$

2.3. Лексеме са основним значењем предмета развиле су значења носилаца карактерних особина метафоричким преношењем мотивисаним семантичким компонентама које се односе на њихову намену, функцију, начин израде, облик, састав, изглед и сл.: балван, будак и буздован у значењу 'прост, неотесан, глуп човек', крискиндла 'девојка која воли да се кинђури' ${ }^{26}$, опирача 'женска особа лошег карактера' ('крпа којом се пере посуђе'), отпадина 'особа која не живи у складу са друштвеним нормама' ('отпадак од дрвета које се цепа, сече, теше и сл.'), ћускија (3) 'глупак' - „Е баш је ћускија: сто пути да читаш једну песму, не да утуби ни први ред”, ћускија (5) 'пијанац'27, чегртаљка 'особа која много прича, брбља', иило 'продорна, окретна, способна особа; немирно, несташно дете'. Код појединих лексема, као што су опирача, отпадина, шило, чегртаљка, лакше се уочавају семантичке компоненте примарног значења које су биле подстицај за развој наведених метафоричких значења. Извесне заједничке одлике денотата, односно заједничке семе, могу се пронаћи код четири именице које реализују значење интелектуално ограничене, глупе особе. Уочљиве су, на пример, карактеристике какве су спољашња грубост, необрађеност, 'неотесаност', физичка тежина, тврдоћа, затим - посебно када су у питању

\footnotetext{
${ }^{25}$ Слично је и у речницима књижевног језика - J. Јовановић (2012: 93) наводи потврду само за лексему Циганин са значењем заснованим на колективном стереотипу.

${ }^{26}$ Примарно значење и једно од секундарних значења ове именице су: 1. 'бомбона умотана у украсни папир, којом се кити јелово дрво за Нову годину или Божић'; 2. б. 'одсечено јелово дрво које се искити за Нову годину или Божић'. Значење носиоца карактерне особине може се извести из наведеног секундарног значења: накићена јелка $\rightarrow$ накићена, накинђурена девојка $\rightarrow$ девојка која воли да се кити, кинђури. Међутим, подаци о местима на којима су потврђена значења ове лексеме не иду у прилог таквој претпоставци. Наиме, примарно значење потврђено је у истим местима као и значење носиоца особине, док је значење 26 потврђено само у једном месту, различитом од осталих, што посредно упућује на примарно значење као на изворно у овом метафоричком преносу номинације.
}

27 Значења лексеме Ћускија која се односе на карактерне особине могла су настати преко поредбених фразеологизама као што су глуп као ћускија (РСЈ), односно тупав ко ћускија (РСГВ) и пијан као ћускија (РСЈ). У РСГВ значење ове лексеме које се односи на глупу, ограничену особу уобичајеније је и потврђено је на више места, док је значење 'пијанац' забележено на једном пункту. Метафоричка веза између лексема ћускија и пијанаи јаснија је када погледамо и поредбене фразеологизме са придевом пијан као основом поређења који су регистровани у РСАНУ: уз придев пијан наводе се и изрази пијан као батина/клада/летва/ метла/паъ/секира/ћускија. Поредбени чланови фразеологизама су, дакле, углавном издужени предмети који не могу остати у усправном положају без ослонца, односно који након губитка ослонца доспевају у хоризонтални положај. На основу тога се остварује асоцијативна веза са понашањем човека који је у пијаном стању. 
алатке и оружје - једноставност израде и могућност да се њима удара приликом примене. ${ }^{28}$ Није извесно у којој мери су побројана својства предмета важна у сваком појединачном случају преноса номинације на човека.

У ову лексичку скупину може се сврстати и турцизам токмак, према PCJ - 'маљ, бат; топуз'. Предметно значење није регистровано у РСГВ, где је именица токмак дефинисана само као 'блесав човек, простак, незналица, глупан'.29

Што се тиче ареалне распрострањености, судећи по броју пунктова на којима су забележене, у одговарајућим значењима широко су заступљене именице будак (17 пунктова), шило (10) и ћускија у значењу 'глупак' (9).

2.4. Неколико семантичких реализација које се односе на човека као носиоца карактерне особине настало је преношењем номинације са натприродних бића из сфере митологије и религије. Метафоризација је мотивисана семантичким компонентама које су засноване на представама припадника језичког колектива о особинама бића у чије постојање се верује (или се некад веровало): аждаја 'зла, опака жена'; ала 'прождрљив, незасит човек'; анатемьак ${ }^{30}$ 'несташко, обешењак'; анђео/анђо/анђев 'особа анђеоских особина - оличење лепоте, љупкости, доброте и сл.'; вештица и каракониула $a^{31}$ 'зла жена'; враг, дракул и ђаво 'живахна, несташна особа, шаљивџија, враголан'; сотона 'зла особа'. Грађа показује да су нешто фреквентније лексеме којима се примарно именују натприродна бића као оличење зла, а секундарно зле особе. Поред тога, блискозначне лексеме враг, дракул, ђаво

${ }^{28}$ Неке од наведених заједничких карактеристика предмета који се асоцијативно повезују са
глупом особом издваја Ј. Јовановић (2018: 386).
${ }^{29}$ Везу између конкретног и метафоричког значења ове лексеме налазимо нпр. у српском
призренском говору, где је именица токмак развила и значење човека са одговарајућом
физичком особином, посредством којег је могло настати и пренесено значење слично оном
у РСГВ (в. МИЛОСАВљЕВИЋ 2014: 232). Ова врста секундарног именовања добро се
уклапа у поменути модел метафоризације у који улазе предмети једноставне израде што
служе за ударање, тако да значење регистровано у РСГВ није морало настати преко физичке
особине. Понекад није извесно како су настала савремена метафоричка значења појединих
лексема страног порекла- да ли семантичким ширењем у оквиру лексичког система српског
језика, после адаптације, или директним преузимањем тих значења из страног језика и
другостепеним формирањем метафоричког односа у оквиру полисемичке структуре. Такав
је нпр. случај лексеме дудук, чије се значење са особом као денотатом - 'глуп, ограничен
човек' изводи из појединих карактеристика предмета који ова лексема примарно означава -
'свирала без писка' (уп. ШТАСНИ 2013: 94 ; ЈОВАНОВИЋ 2018: 385$)$. Међутим, у турском
језику лексема dӥдйk у одређеном регистру (који је у савременом турско-српском речнику
(ЂИНЂИЋ 2014) означен као 'арго') има значење особе - 'дудук, клипан, звекан'. На
могуће директно преузимање метафоричког значења из турског језика упућују и одређени
дијалекатски говори српског језика у којима ова лексема није забележена у значењу предмета.

${ }^{30}$ Примарно значење ове лексеме у РС је 'нечастива сила, зао дух, ђаво'.

${ }^{31}$ У РСГВ није регистровано основно значење ове лексеме - 'вештица, авет, утвара' (РМС). 
и анатемъак активирањем других, перифернијих сема ${ }^{32}$ реализују метафоричка значења носилаца оних особина које се могу сматрати позитивним или неутралним.

2.5. Називи биљака семантички су непродуктивни за овај тип другостепеног именовања човека: ${ }^{33}$ буква 'прост, неотесан, глуп човек' - „Јао, букво једна, јел чујеш како ти толмачи"; крпигуз ${ }^{34}$ и чичак 'досадна, наметљива особа'; тиква 'глупак, глупан, будала'35. Семантичке компоненте примарног садржаја којима су мотивисане наведене фитонимске метафоре углавном не спадају у семе колективне експресије, већ се махом односе на физичке, материјалне одлике одређених биљних врста. На основу тога може се закључити да процес метафоричке трансформације код фитонима (са човеком као циљним садржајем) често функционише на сличан начин као код предмета или материје, а не као код зоонима, са којима се називи биљних врста често сврставају у исту групу.

2.6. Неколико именица које примарно означавају материју развиле су такође одговарајуће семантичке реализације које су предмет ове анализе. Асоцијативна веза између секундарног значења лексеме жеравица 'окретан, вредан, темпераментан човек' - „То ти је жеравица од човека” и њеног примарног значења: 'усијани остаци чврстог горива' настала је на основу једне од основних карактеристика наведеног појма - усијаности, врелине, топлоте. Метафоричко повезивање вреле материје са човеком који је темпераментан или окретан успостављено је, ако се у обзир узме разлагање садржаја на семантичке компоненте, преко појединих заједничких сема које деле придеви темпераментан, окретан и врео, врућ у одређеним значењима. ${ }^{36}$ Именица жеравица је највероватније лексикализовани деминутив (уп.

32 То су семантичке компоненте којима су мотивисани и творбени процеси код лексема враголаст, Ђаволаст, враголан и сл., а које се не наводе као семантички елементи основног значења.

${ }^{33}$ Ј. Јовановић (2012: 89) истиче да се у описним речницима експресивна вредност фитонима региструје обично у склопу различитих израза.

34 Значења лексеме крпигуз $(1,2)$ односе се на врсте чичка. Као мотивација за секундарно именовање послужиле су вероватно семе које нису експлициране у дефиницији, а које се тичу могућности те биљке да се лако закачи, залепи за нешто или неког и да на тај начин смета, 'досађује' (уп. у РМС фразеологизам 'прилепио, прикачио се као чичак уз пасји реп каже се ономе ко је наметљив, досадан'). Значајан експресивни потенцијал ова именица поседује и захваљујући својој формалној страни, гласовном склопу, односно творбеносемантичкој структури императивне сложенице. Од свих наведених лексема из ове групе, именица крпигуз је најшире посведочена у одговарајућем значењу - на 9 пунктова.

35 Значење носиоца особине добијено је синегдохом преко метафоричког значења тиква (3a) 'глава' (уп. ШТАСНИ 2013: 101).

${ }^{36}$ Поред наведених придева, могу се издвојити семе, односно неправи синоними, као што 
у РСГВ одредницу жерава), па је могуће да извесни остатак деминутивно-хипокористичног значења који носи формант -ица додатно потврђује афирмативни став према особи која се именује на тај начин. Изразито афирмативно пренесено значење има и лексема мелем 'који је пун доброте, благости, племенитости' - „Лаза је био мелем”.

Није потпуно транспарентна веза између значења која се у РСГВ приписују лексеми куља: секундарно 'неодлучан, стидљив човек, млакоња' „Не волем кад је човек куља, него да приповеда, да буде паметан”, и примарно 'јело од куваног кукурузног брашна'. Метафоризација лексема са значењем јела не даје често реализације које се односе на човека. Уколико су наведена значења асоцијативно повезана, могуће је да њихову везу треба тражити у одређеним карактеристикама материје која чини јело - густини, житкости, односно недостатку чврстине, тврдоће (меком материјом именује се човек без чврстине, мек, млак човек). ${ }^{37}$

Лако су уочљиви елементи семантичког садржаја који су били мотиватори ширења полисемичке структуре у случају лексема Ђубре 'зла, некарактерна, непоштена особа', поган 'покварена, опака, рђава особа' ('измет'), отров 'зла, опака, опасна особа'. Човеку се приписују негативне моралне особине његовим довођењем у појмовну везу са материјом према којој типски представник језичке заједнице има одређену одбојност или је сматра опасном, чиме се постиже изразита деградација људског бића.

\section{3. Значења настала деловањем метонимије и синегдохе}

3.1. Као што је већ поменуто, метонимија и синегдоха као механизми ширења полисемичке структуре имају слабу продуктивност у овој класи именица. Значења настала преко ових лексичких механизама веома су слабо заступљена и забележена су на малом броју пунктова. Метонимијске трансформације карактеристичне су пре свега за поједине апстрактне именице које примарно реализују значења стања или особине. Према типологији метонимијских транспозиција коју даје М. Ковачевић (1999: 178-188) преноси овог типа сврставају се у каузалну метонимију. По метонимијском моделу 'стање/особина $\rightarrow$ носилац стања/особине' реализује се секундарно значење лексема безбрига 'безбрижан човек, весељак' - „Пусти њега он је

су живахан, страстан, страствен, ватрен итд., које налазимо у дефиницијама ових речи у описним речницима. То су махом компоненте које се тичу брзине и интензитета емотивног или физичког реаговања неке особе.

\footnotetext{
${ }^{37}$ У прилог оваквој мотивисаности метафоричког преноса може се навести и пример лексеме пекмез, која у РСАНУ има секундарно значење слабашна, нејака особа, слабић, мекушаи (y физичком и карактерном смислу). На представу о пекмезу као нечему што није тврдо, чврсто - указује и његова етимологија у турском језику. Према речнику П. Скока, форманти ове лексеме су придев реq 'тврд' и негативна постпозиција -теz.
} 
права безбрига" и небрига 'особа која се ни за шта, ни о коме не брине'. У ову скупину може се сврстати и лексема горопад 'који бесни, који се љути' ('бес, љутња'), са примарним значењем емоције, односно стања (који се због учесталости испољавања транспонују у категорију особине).

Најбројнија али и семантички најразуђенија скупина лексема обухвата апстрактне именице са примарним значењем одређене активности, поступка, понашања и сл.: заврзлама 'сметењак, шепртља' ('збрка, пометња'); измотација 'жена која се измотава'38 ('неозбиљан поступак, шала'); керефека 'луцпрда', тј. 'луцкаста, неозбиљна, непредвидива особа' ('измотавање, кревељење, лудорија'); несрећа 'особа која својим понашањем прави проблеме' - „Тај је несрећа једна, напије се и лумпује и свашта ради”; оnсена 'кокетна женска особа' ('варка, обмана, превара; трик, чаролија'); nетљљавина 'неспретна особа' ('неспретно, наопако урађен посао'). Нешто је сложенија мотивисаност секундарног именовања у случају лексеме дремеж 'лењ човек', са апстрактном основном реализацијом 'сањивост, поспаност' . Може се претпоставити да је повезаност наведених значења остварена преко нереализованог (или незабележеног) значења сањив, поспан човек, поспанко, тако да је веза тог значења са примарним значењем лексеме дремеж метонимијска, а веза са њеним секундарним значењем метафоричка.

Изван класе примарно апстрактних именица метонимијско именовање човека према карактерној особини добијено семантичком деривацијом изузетно је ретко. У грађи из РСГВ ту врсту проширивања семантичке структуре проналазимо код именица са примарним значењем предмета (који је у ванјезичком односу блискости са особом која се именује). Овај тип метонимијског преноса одликује недостатак регуларности и негативна експресивност циљног садржаја. Тако се именицом чутура погрдно означава 'пијандура', тј. 'особа која често и много пије алкохолна пића, која се често опија', 39 а лексемом конђа именује се 'оштроконђа', тј. 'зла, опака жена' „Кад хоће да нагрде неку жену, кажу јој: Та конђа!”. Примарна семантика именице конђа везана је за предмете које користе жене: (1a) 'мали дрвени обруч пресвучен тканином око кога удате жене обавијају косу', односно (1б) 'уметак од косе, вуне и сл. који замењује природну косу'.

Нетипичност наведених метонимијских трансформација огледа се у њиховој недовољној регуларности или нерегуларности, малом броју при-

\footnotetext{
${ }^{38}$ Речничка дефиниција секундарног значења које се односи на човека упућује на глагол измотавати се као на могућу мотивну реч у творбеном процесу. Иако постоји јасна веза између глаголске лексеме и наведеног значења (хибридне) творенице измотащија, највероватније је ово значење добијено семантичком деривацијом (заснованој на метонимији), јер, како наводи И. Клајн (2003: 250-251), суфикс -ација „означава глаголску радњу, с тим што, као и увек код именица ове врсте, многе накнадно добијају и предметно или апстрактно именичко значење”.

${ }^{39} \mathrm{O}$ реткости и нерегуларности овог типа метонимијског преноса говори и податак да ни у грађи из описних речника књижевног језика нема другог примера, изузев лексеме чутура, који би био потврда за исти тип метонимије (в. ЈОВАНОВИЋ 2018: 210).
} 
мера који их илуструју у РСГВ, односно малом броју пунктова на којима су потврђени (свака реализација само на по једном пункту), затим у експресивном циљном садржају и могућој ограничености на одређене парадигматске облике именице, тако да се за неке од наведених примера не може са сигурношћу тврдити да спадају у лексичку метонимију (уп. ДРАГИЋЕВИЋ 2007: 173).

3.2. У анализираној именичкој грађи синегдоха се јавља само као лексички процес који је удружен са одговарајућим метафоричким повезивањима двају значењских садржаја. Деловање најтипичније синегдохе 'део $\rightarrow$ целина' може се уочити у полисемичкој структури именица ғушика 'особа сумњивог морала, протува, нитков; ружна особа' и тиква 'глупак, глупан, будала'. Активирање механизма синегдохе омогућено је тиме што обе наведене лексеме имају и метафоричка значења експресивних назива за делове човечијег тела, мотивисана семама положаја и облика (ъушка), односно облика и садржаја (тиква): ьушка (2) 'предњи део лица код човека, посебно уста и нос', тиква (3a) 'глава' (уп. ШТАСНИ 2013: 101; ЈОВАНОВИЋ 2018 : $225)$. Примери именовања човека збирним појмовима стока и марва - са истим примарним лексичким значењем, али различитим пренесеним значењима: стока 'груба, бездушна особа' и марва 'особа лошег карактера', односно 'лења, особа, нерадник' - могу се посматрати као резултат заједничког деловања метафоре засноване на конотативним семама и синегдохе 'целина $\rightarrow$ део' (в. ЈОВАНОВИЋ 2018: 229).

\section{4. Закључне напомене}

Анализа лексичке грађе из Речника српских говора Војводине потврдила је универзалност одређених карактеристика полисемичког ширења именица којима се секундарно денотира човек са неком карактерном особином. Може се закључити да прототипична именица са секундарним значењем носиоца карактерне особине у испитиваним дијалекатским говорима примарно означава или животињу или човека, и да реализује значење у домену човекових моралних особина (злоба, рђавост) или интелигенције (глупост). Вероватно ће то потврдити и друга истраживања овог сегмента лексичког система у различитим говорима српског језика. Доминантност зоонима у овој сфери показује и њихова најшира ареална заступљеност у одговарајућим значењима. Највећи број реализација добијених преносом номинације са човека регистрован је код лексема са примарним значењем особе која има неко занимање, службу или друштвени статус, док су ареално најзаступљеније лексеме чије се непренесено значење односи на носиоца физичке особине. Друге важне лексичке групе које су уобичајени извори 
метафоричких асоцијација овог типа, обухватају именице које примарно денотирају предмете, натприродна бића, биљке и материју. Фитоними су изузетно семантички непродуктивни за овакво другостепено именовање човека и њихова метафоризација се битно разликује од зоонимске. Метонимијска значења карактеристична су за апстрактне именице са значењима поступка, активности, понашања и сл. или одређеног стања и особине. Одликује их слаба регуларност или нерегуларност и мали број потврда у РСГВ. Синегдоха као лексички механизам јавља се само у понеком примеру, и то удружено са метафоричком трансформацијом.

\section{Цитирана литература}

ГОРТАН-ПРЕМК, Даринка. Полисемија и организащија лексичког система у српскоме језику. - 2. изд. Београд: Завод за уџбенике и наставна средства, 2004.

ДРАГИЋЕВИЋ, Рајна. Лексикологија српског језика. Београд: Завод за уџбенике, 2007.

ЈОВАНОВИЋ, Јована. „Културни стереотипи у лексичком фонду српског језика и лексикографски опис колективно експресивних лексема у дескриптивном речнику". Карацић 4 (2012): стр. 78-95.

ЈОВАНОВИЋ, Јована. Лексика погрдног значења у именовању човека у српском језику (необјављена докторска дисертација). Београд: Филолошки факултет, 2018.

КЛАЈН, Иван. Творба речи у савременом српском језику. Други део. Суфиксација и конверзија. Београд - Нови Сад: Завод за уџбенике, Матица српска, Институт за српски језик САНУ, 2003.

КОВАЧЕВИЋ, Милош. „Метонимија и синегдоха”. Српски језик IV/1-2 (1999): стр. 171-203.

МИЛОСАВЉЕВИЋ, Тања. „Метафоричка номинација човека у српском призренском говору". Српски језик, књижевност, уметност. Књига 1: Вишезначност у језику (2014): стр. 229-239.

НОВОКМЕТ, Слободан. Семантичка анализа лексема које означавају животиње у савременом српском језику (необјављена докторска дисертација). Београд: Филолошки факултет, 2016.

РАНЂЕЛОВИЋ, Ана. „Метафорична значења зоонима која се односе на људске особине". Наш језик XLIII/3-4 (2012): стр. 89-105.

ШТАСНИ, Гордана. Речи о човеку. Нови Сад: Филозофски факултет, 2013.

\section{Извори}

AРCJ: Предраг Пипер, Рајна Драгићевић, Марија Стефановић. Асощијативни речник српскога језика. Београд: Београдска књига, 2005. 
ЂИНЂИЋ, Марија. Yeni Türkçe-Sırpça Sözlük. Ankara: Türk Dil Kurumu Yayınları, 2014.

PMC: Речник српскохрватскога књижевног језика, I-VI. Нови Сад: Матица српска (I-III и Загреб: Матица хрватска), 1967-1978.

РСАНУ: Речник српскохрватског књижевног и народног језика, I-XX. Београд: Српска академија наука и уметности, Институт за срп(скохрват)ски језик, 1959-2017.

РСГВ: Речник српских говора Војводине, 1-10. Нови Сад: Матица српска, 2000-2010.

РСЈ: Речник српскога језика. Нови Сад: Матица српска, 2011.

СКОК: Petar Skok, Etimologijski rječnik hrvatskoga ili srpskoga jezika. Knjige 1-3. Zagreb: Jugoslavenska akademija znanosti i umjetnosti, 1971-1973.

Nikola M. Sanković

\section{NOUNS WITH SECONDARY MEANINGS USED IN NAMING PEOPLE WITH SPECIFIC PERSONALITY FEATURES IN THE DICTIONARY OF SERBIAN SPEECH IN VOJVODINA}

The aim of this paper is to analyze the lexemes of the Serbian speeches in Vojvodina whose secondary meanings are used in naming people with specific personality features. The research material was excerpted from the most prominent dialect dictionary in which the lexemes of these speeches are presented. The most important noun groups were distinguished according to the transformation potential of their primary lexical meanings. Given the type of material we analyzed, the lexical meanings were viewed as a set of semantic components. Also, a description of metaphorical and metonymical transfers were given on the examples of the analyzed lexemes.

Keywords: Serbian language, speeches in Vojvodina, nouns, personality features, semantic derivation, metaphor, metonymy. 